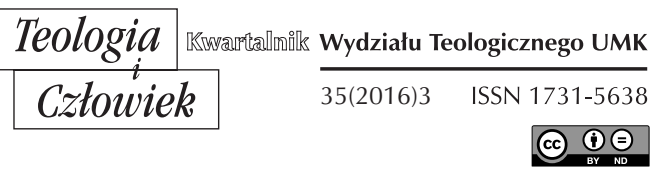

MARCIN RZEPKA*

KRAKÓW

\title{
PRZEBUDZENIE MUZUKMAŃSKIE A ŚWIAT CHRZEŚCIJAŃSKI. PRAGMATYKA DIALOGU MIĘDZYRELIGIJNEGO W POREWOLUCYJNYM IRANIE
}

DOI: http://dx.doi.org/10.12775/TiCz.2016.037

\section{WPROWADZENIE}

Rewolucja islamska dokonała przewartościowania religii w wymiarze politycznym i społecznym, wprowadzając w Iranie nową koncepcję państwa ${ }^{1}$. Wyrazem nowej tożsamości politycznej stała się konstytucja przyjęta w grudniu 1979 roku, będąca tyleż owocem negocjacji pomiędzy różnymi grupami społecznymi, co syntezą poglądów ajatollaha Ruhollaha Chomejniego, pierwszego przywódcy² Islamskiej Republiki Iranu

* Marcin Rzepka - slawista (1999) i orientalista (2003). W 2008 uzyskał stopień doktora na Wydziale Filologicznym Uniwersytetu Jagiellońskiego na podstawie rozprawy o przekładach Biblii na języki irańskie. Od 2008 pracownik Instytutu Historii Uniwersytetu Papieskiego Jana Pawła II w Krakowie. Członek towarzystw naukowych: Societas Iranologica Europaea oraz Society for Pentecostal Studies (marcin.rzepka@upjp2.edu.pl).

1 Artykuł powstał w ramach projektu finansowanego przez Narodowe Centrum Nauki na podstawie umowy UMO-2013/11/B/HS1/03962.

2 Przywódcą Iranu (rahbar) jest uczony muzułmański sprawujący władzę dożywotnio jako wali-je fakih - w latach 1979-1989 urząd sprawował ajatollah Ruhollah 
(Dżomhuri-je Eslāmi-je Irān) ${ }^{3}$. Konstytucja wskazując na nadrzędną funkcję religii w wymiarze wewnątrzpaństwowym oraz międzynarodowym uczyniła $\mathrm{z}$ dialogu międzyreligijnego użyteczne narzędzie polityki wewnętrznej oraz dyplomacji ${ }^{4}$. Religia zaczęła odgrywać nadrzędną rolę w kategoryzacji grup mniejszościowych w Iranie oraz zdeterminowała zachowania tego kraju na forum międzynarodowym. Nie sposób zatem oddzielić podejmowanych przez Iran działań w ramach dialogu międzyreligijnego od koncepcji politycznych rozwijanych w tym kraju w czasie rewolucji.

Rewolucja stała się matrycą interpretacyjną wydarzeń rozgrywających się na Bliskim Wschodzie oraz wygodnym narzędziem wyznaczania granic postrzegania i interpretowania inności. Bez zrozumienia miejsca i roli religii w porewolucyjnym Iranie trudno zatem mówić o koncepcji dialogu, jego przejawach czy w końcu sposobach jego realizacji w tym kraju. Przykładem złożonej natury prowadzonego przez Iran dialogu niech będzie konferencja - jej tytuł został przywołany w tytule niniejszego artykułu - „Przebudzenie muzułmańskie a świat chrześcijański” (Bidāri-je eslāmi va dżahān-e masihijat), która odbyła się w irańskim mieście Kom we wrześniu 2011 roku $^{5}$. Konferencja ta była próbą zinterpretowania wydarzeń rozgrywających się $\mathrm{w}$ krajach arabskich okrzykniętych mianem „arabskiej wiosny” (w języku perskim: bahār-e arabi) w środowisku irańskich elit politycznych i religijnych. W istocie jednak dała możliwość ponownego określenia pozycji Iranu na Bliskim Wschodzie poprzez przywołanie rewolucji z 1979 jako źródła inspiracji dla świata arabskiego ${ }^{6}$.

Chomejnin, po jego śmierci w 1989 roku, jego następcą został ajatollah Ali Chamenei. Prezydent ( ra'is-e dżomhur) jest natomiast wybierany w wyborach powszechnych na czteroletnią kadencję.

${ }^{3}$ Przy zapisie wyrazów perskich przyjęto zasadą maksymalnego ich spolszczenia wprowadzając jednak rozróżnienie między samogłoskami $a$ i $\bar{a}$, spółgłoski oddawane są literą $q$.

${ }^{4}$ M. Rasekh, Are Islamism and Republicanism Compatible? A Theory of the Unchangeable Principles of the Constitution of the Islamic republic of Iran, w: The Shari'a in the Constitutions of Afghanistan, Iran and Egypt - Implications for Private Law, red. N. Yassari, Tübingen 2005, s. 113-121.

${ }^{5}$ Informacje o konferencji przytaczam za irańską agencją informacyjną Fars News, zob. http://www.farsnews.com/newstext.php?nn=13900623000173 [dostęp: 10.12.2015].

${ }^{6}$ Różnice między rewolucją irańską a przemianami zachodzącymi w świecie 
Znamienne wydaje się zrezygnowanie z określenia „wiosna” (bahār) na rzecz „przebudzenie” (bidāri). Ukazuje ono istotę irańskiego myślenia o religii i rewolucji w kontekście rywalizacji między Iranem a państwami arabskimi w regionie. Zdaniem irańskich duchownych krajom arabskim potrzebna jest re-islamizacja, przebudzenie, a w konsekwencji przyjęcie irańskiego modelu rządów. A zatem kontakty między Iranem a światem arabskim, motywowane religią i polityką, wpływają na relacje szyicko-sunnickie $\mathrm{w}$ obrębie islamu ${ }^{7}$, stanowiąc tym samym jeden $\mathrm{z}$ istotnych wymiarów dialogu religijnego w tym kraju.

Chrześcijaństwo, które $\mathrm{w}$ zasadzie od czasu rewolucji stanowi $\mathrm{w}$ Iranie przedmiot debat podejmowanych przez duchownych szyickich, uczonych oraz dyplomatów irańskich, było przedmiotem refleksji w czasie przywołanej powyżej konferencji w Kom. Wziął w niej udział ówczesny ambasador Islamskiej Republiki Iranu przy Stolicy Apostolskiej hodżatoleslam $^{8}$ Ali Akbar Naseri ${ }^{9}$, który w swoim wystąpieniu akcentował rolę dwóch światowych centrów religijnych: jednego znajdującego się w Kom, drugiego zaś w Watykanie. Dowodził, że powinny one współpracować ze sobą, a tym samym przyznawał wartość podejmowanych przez nie inicjatyw na rzecz dialogu katolicko-szyickiego ${ }^{10}$. Zagadnienia związane

arabskim są jednak bardzo istotne, zob. A. Adib-Moqaddam, On the Arab revolts and the Iranian revolution. Power and resistance today, London 2014, s. 2-5.

7 Doniosłym przykładem konfliktów i rywalizacji są relacje między Islamską Republiką Iranu a Arabią Saudyjską, ich kształt polityczny w dużym stopniu determinuje interpretacja islamu, zob. S. Moban, Saudi Arabia and Iran. Power and rivalry in the Middle East, London-New York 2015, s. 107-140.

8 Przywoływane terminy: hodżatoleslam, ajatollah ukazują zróżnicowanie hierarchiczny w obrębie duchowieństwa (ruhanijat) szyickiego. Wykształcenie się hierarchii związane było z rolą modżtahedów, uczonych szyickich mających prawo (edżāze) do interpretowania prawa oraz wydawania orzeczeń religijnych. Znana dziś struktura: mulla (achund) - hodżatoleslam - ajatollah wykształciła się w XX wieku, zob. M. Momen, An introduction to Shi'i Islam, New Haven-London, 1985, s. 184-207; H. Algar, Āyatullāh, Encyclopæedia Iranica, III/2, s. 133, artykuł w wersji on-line http://www.iranicaonline. org/articles/ayatallah [dostęp: 11.12.2015].

9 Obecnie ambasadorem jest hodżatoleslam Mohammad Taher Rabbani.

${ }^{10}$ W 2011 roku miesięcznik „Inside the Vatican” (czerwiec-lipiec) opublikował wywiad z ambasadorem. Naseri podkreślał wagę kontaktów oraz działań na rzecz dialogu, wspomniał również o wizycie kardynała Jean-Louis Taurana, przewodniczącego Papieskiej Rady ds. Dialogu Międzyreligijnego w Iranie, wywiad dostępny on-line: http://www. 
z chrześcijaństwem, zwłaszcza zaś trudny los chrześcijan w krajach arabskich ogarniętych wojną, dominowały również w innych wystąpieniach konferencyjnych. Hodżatoleslam Mohammad Masdżed-dżāme’i, irański ambasador w Watykanie w latach 1991-1996, podkreślał historyczne znaczenie obecności chrześcijan na Bliskim Wschodzie oraz ich wkład w rozwój całego regionu. Wyraził przy tym obawy o przyszłość relacji między chrześcijanami a muzułmanami, naiwnie twierdząc, że obecne animozje są wynikiem antagonizowania chrześcijan i muzułmanów przez obalonych już dyktatorów. W tym kontekście został przywołany Iran jako „modelowy” kraj na Bliskim Wschodzie i przykład dobrych relacji między muzułmanami a chrześcijanami. Relacje te określa konstytucja, która mniejszościom religijnym gwarantuje, choć w ograniczonym zakresie, partycypację w życiu politycznym, społecznym oraz kulturowym państwa ${ }^{11}$.

Niniejszy artykuł opiera się na założeniu, że dialog międzyreligijny w Iranie traktowany jest jako część szerszego projektu politycznego. Przekonuje o tym przywołana powyżej konferencja. Warto zatem na wstępie podkreślić dwa wymiary dialogu w kontekście irańskim: wewnętrzny, którego przedmiotem będą mniejszości religijne zamieszkujące ten kraj, oraz zewnętrzny, stanowiący z jednej strony promocję Iranu, z drugiej zaś narzędzie dyplomacji. Nie sposób przy tym pominąć dychotomii irańskiej kultury religijnej będącej pochodną podziałów politycznych oraz odmiennych interpretacji irańskiego etosu rewolucyjnego ${ }^{12}$. W wymiarze zewnętrznym podejmowane przez Iran inicjatywy dotyczyć będę przede wszystkim chrześcijaństwa, szczególnie zaś Kościoła rzymsko-katolickiego.

\section{UWARUNKOWANIA DIALOGU MIĘDZYRELIGIJNEGO W IRANIE}

Wskazując na czynniki warunkujące rozwój dialogu międzyreligijnego w Iranie, należy zwrócić uwagę na ogromne znaczenie religii

lastampa.it/2011/08/30/vaticaninsider/eng/world-news/the-relations-between-the-iranianembassy-and-the-holy-see-dIJoJC9gwqJE53EpTwa2cP/pagina.html [dostęp: 10.12.2015].

${ }^{11}$ Konstytucja irańska wprowadza kategorię mniejszości religijnych (aqalijat-e dini) - o „rozpoznanych” mniejszościach szerzej w dalszej części artykułu. E. Sanasarian, Religious Minorities in Iran, Cambridge 2000.

${ }^{12}$ Sh. T. Hunter, Iran Divided. The historical roots of Iranian debates on identity, culture, and governance in the twenty-first century, New York-London 2014. 
w praktyce politycznej państwa. Możemy zatem oczekiwać, że dialog odpowiadać będzie pragmatyce i kalkulacjom politycznym rządzących. W istocie od powstania Islamskiej Republiki Iranu daje się zauważyć ewolucję rozumienia dialogu międzyreligijnego pokrywającą się do pewnego stopnia ze zmianami zachodzącymi na scenie politycznej. Wydaje się, że w odniesieniu do Iranu możemy wyróżnić przynajmniej trzy etapy kształtowania się relacji między szyizmem a innymi religiami, a przy tym również określania i definiowania kontaktów międzypaństwowych. Pierwszy etap związany jest z budowaniem Islamskiej Republiki Iranu i działalnością ajatollaha Chomejniego. Okres ten, trwający do 1989 roku, należałoby raczej określić jako czas negocjacji, a nie dialog sensu stricto. Mamy bowiem do czynienia z próbą wyznaczenia przez Iran - Republikę Islamską - granic partycypacji społecznej oraz praw i swobód mniejszości religijnych rozpoznanych przez prawo, a także z określeniem stanowiska Iranu w kwestiach międzynarodowych. W wymiarze wewnętrznym polega to na zdefiniowaniu roli, jaką szyizm ma odgrywać w nowej rzeczywistości politycznej. Warto zwrócić uwagę, że szyizm w interpretacjach zwolenników rewolucji stał się podstawowym składnikiem tożsamości irańskiej, stąd dość proste, acz mające poważne konsekwencje, założenie, że Irańczyk to osoba wyznająca szyizm. Takie założenie wpływa na postrzeganie konwersji religijnej jako $\mathrm{z}$ jednej strony aktu religijnego, $\mathrm{z}$ drugiej zaś postawy politycznej będącej pogwałceniem dominującego projektu tożsamościowego ${ }^{13}$.

Szyizm będący podstawą systemu politycznego dzisiejszego Iranu został przedefiniowany w duchu rewolucji trzecioświatowych, zdradzając przy tym pokrewieństwo z teologią wyzwolenia. Irański badacz Hamid Dabashi przywołuje określenie „teologia niezadowolenia” w odniesieniu do irańskiej myśli teologicznej podzielanej przez Chomejniego i jego zwolenników ${ }^{14}$. Dodatkowo wyraźnym przejawem ideologii irańskiej zakładającej podział świata na prześladowanych i prześladujących - będzie

13 Ziya Meral interpretuje konwersje religijne w Iranie jako zagrożenia dla bezpieczeństwa państwa, zob. tenże, Minority Religions and Islam: Religious minorities and conversion as national security threats in Turkey and Iran, w: State Responses to Minority Religions, red. David M. Kirkham, Burlington 2013, s. 35.

${ }^{14}$ H. Dabashi, Theology of Discontent. The Ideological Foundation of the Islamic Revolution in Iran, New Brunswick-London 2006. 
traktowanie muzułmanów (Irańczyków) jako społeczności uciemiężonej. Przy takiej interpretacji trudno oczekiwać, by problemy innych religii znalazły się w centrum uwagi. Ma to jednak jeszcze głębszy wymiar. Dotyczy bowiem tożsamości Irańczyków, tożsamości, która jest zagrożona, której należy bronić. W szerszym ujęciu dotyczy to świata muzułmańskiego i roli Iranu w odnowie islamu.

W forsowanej przez Chomejniego wizji wspólnej tożsamości muzułmańskiej nie ma miejsca, przynajmniej teoretycznie, na partykularyzm muzułmański, który mógłby przyjąć postać nacjonalizmu. Postulowana jedność - bynajmniej nie na płaszczyźnie idei - mogła być osiągnięta w radykalnym sprzeciwie wobec Zachodu. A zatem perspektywę dialogu bardzo silnie wyznaczała praktyka, a nie doktryna, przyjęcie określonych postaw, a nie rozważania teoretyczne. Stanowisko przywódców irańskich wobec świata zewnętrznego oraz programowy sprzeciw wobec dominujących układów międzynarodowych, potwierdzony niejako zajęciem ambasady amerykańskiej w Teheranie 4 listopada 1979 roku, powodowało izolację Iranu na forum międzynarodowym, dając jednocześnie Iranowi możliwość zawierania sojuszy z państwami marginalizowanymi dotąd $\mathrm{w}$ światowej polityce.

W odniesieniu do Iranu sankcje polityczne nie oznaczały bynajmniej niemożności oddziaływania na polityków irańskich poprzez wykorzystanie religii i autorytetów religijnych. Doskonałym przykładem może być list Jana Pawła II wysłany do ajatollaha Chomejniego na prośbę prezydenta Jimmy’ego Cartera po uwięzieniu pracowników ambasady amerykańskiej ${ }^{15}$. Mamy więc do czynienia z bardzo ścisłym związkiem między religią a polityką, który faktycznie warunkuje rozumienie dialogu międzyreligijnego w Iranie. Podkreślmy jednak, że dla wspomnianego okresu (lata 1979-1989) bardziej odpowiedni wydaje się termin negocjacje, a nie dialog. Niewątpliwie jednak mamy do czynienia z określeniem podmiotów przyszłego dialogu (jednym z partnerów będzie Kościół rzymsko-katolicki) oraz wyznaczenie przestrzeni dialogu (będą to, między innymi, bieżące problemy polityczne oraz źródła autorytetu religijnego). $\mathrm{W}$ istocie w pierwszej dekadzie istnienia Islamskiej Republiki Iranu nie za-

15 J. Carter, Keeping Faith. Memories of a President, Toronto-New York-London-Sydney 1982, s. 459. 
istniały większe możliwości rozwoju kontaktów międzyreligijnych również ze względu na przeciągającą się wojnę z Irakiem. Symbolicznym zakończeniem tego okresu będzie jednak list ajatollaha Chomejniego wysłany do Michaiła Gorbaczowa w 1989 roku ${ }^{16}$, który wskazując na islam jako remedium na kryzysy społeczne implikuje konieczność podjęcia dialogu między religiami. Islam byłby zatem jedynym możliwym sposobem rozwiązywania rzeczywistych problemów politycznych.

Drugi okres kształtowania się idei dialogu, rozpoczęty po śmierci przywódcy w 1989 roku, cechuje programowe otwarcie Iranu oraz bardziej koncyliacyjna postawa na forum międzynarodowym. Dodatkowo po roku 1989 inne centra władzy, w tym zwłaszcza urząd prezydenta, będą znacznie silniej wpływać na politykę konfesyjną państwa. Kulminacją zmian będzie promowana przez prezydenta Mohammada Chatamiego idea dialogu między cywilizacjami (goftogu-je tamadonhā). Okres ten charakteryzuje się upodmiotowieniem dialogu, który staje się jednocześnie ideą polityczną ${ }^{17}$. Osią cywilizacji w rozumieniu Chatamiego są religie Abrahamowe, stąd w konsekwencji podejmowane w tym czasie inicjatywy dotyczyć będą przede wszystkim chrześcijaństwa, judaizm zaś pojawi się jedynie w wymiarze wewnętrznym państwa. Chatami, teolog szyicki, akcentując konieczność dialogu, dokonał syntezy idei szyickich, myśli irańskiej oraz europejskiej filozofii dialogu, tworząc w ten sposób bardzo istotną ramę ideową dla wszelkich podejmowanych wówczas inicjatyw. Pomimo krytyki upatrującej w projekcie irańskiego prezydenta jedynie przejawów nazbyt rozbudowanej retoryki ${ }^{18}$, przyniósł on wymierne korzyści mniejszościom religijnym w Iranie ${ }^{19}$. Odbił się również wyraźnie w przestrzeni międzynarodowej. Dość wspomnieć o spotkaniu

${ }^{16}$ M. Rzepka, Religion, diplomacy and identity. Some remarks on the ayatollah Khomeini's letter to Gorbachev, „Orientalia Christiana Cracoviensia” 5 (2013), s. 79-86.

17 F. Petito, Khatami' Dialogue among Civilizations as International Political Theory, „Journal of Humanities” 11 (2004) 3, s. 11-29.

${ }_{18}$ G. Tazmini, Khatami's Iran. The Islamic Republic and the turbulent path to reform, London-New York 2009, s. 97.

19 Zob. A. Dallalfar, Negotiated Allegiances: Contemporary Iranian Jewish Identities, "Comparative Studies of South Asia, Africa and the Middle East” 30 (2010) 2, s. $272-296$. 
prezydenta Chatamiego z Janem Pawłem II, które odbyło się 11 marca 1999 roku.

Wspomniane powyżej działania, wyznaczone koncepcją „spotkania między cywilizacjami”, rozpoczynają trzecią fazę kształtowania się idei dialogu w porewolucyjnym Iranie. Można ją określić mianem profesjonalizacji, której przejawem będzie powstawanie wyspecjalizowanych ośrodków zajmujących się dialogiem międzyreligijnym. Celem dialogu, o czym zapewniają irańscy badacze, jest $\mathrm{z}$ jednej strony poznanie innych religii, $\mathrm{z}$ drugiej zaś jego wymiar praktyczny przejawiający się $\mathrm{w}$ działalności społecznej ${ }^{20}$.

Do roku 2005 roku dominującym ośrodkiem promującym ideę dialogu było założone przez prezydenta Chatamiego Międzynarodowe Centrum Dialogu Między Cywilizacjami (Markaz-e bejn-ol-mellali-je goftogu-je tamadonhā) oraz powstały niemal równocześnie Instytut Dialogu Międzyreligijnego (Móassese-je goftogu-je adijān). Instytut został założony przez ówczesnego wiceprezydenta Iranu Mohammada Ali Abtahiego i rozpoczął działalność w 2001 roku. Dziś funkcjonuje jako organizacja pozarządowa. Najstarszą jednak instytucją tego typu pozostaje Centrum Dialogu Religii i Cywilizacji (Markaz-e goftogu-je adjān wa tamadonhāa). Centrum rozpoczęło działalność w 1990 roku przy Ministerstwie Kultury i Przewodnictwa Muzułmańskiego. Obecnie jest to bodaj najlepiej rozwinięta instytucja rządowa zajmująca się problematyką dialogu międzyreligijnego. Stawia sobie ona za cel poznanie innych religii, ich zrozumienie, ale również promocję islamu (szyizmu) oraz walkę $\mathrm{z}$ uprzedzeniami i stereotypami dotyczącymi tej religii ${ }^{21}$. Zajmuje się ona, między innymi, organizacją konferencji, współpracą z innymi organizacjami w świecie o podobnym profilu działania, prowadzi również działalność wydawniczą. Warto również wspomnieć o Uniwersytecie Religii oraz Wyznań (Dāneszgāh-e adjān wa mazāheb) założonym w 2005 roku w Kom. Początkowo działał on jako instytut badawczy przy jednej z uczelni teologicznych w tym niezwykle istotnym dla szyitów mieście. W 2009 roku również w Kom rozpoczął działalność Międzynarodowy Instytut Studiów

${ }^{20}$ M. H. T. Akradi, Piszine-je tārichi-je goftogu-je eslām wa masihijat, Qom 1387 (2008), s. 36-37.

${ }^{21}$ Więcej na stronie internetowej instytutu: http://www.cid.icro.ir/. 
Muzułmańskich (Moa’sesse-je bejn-ol-mellali-je motāleāt-e eslāmi), którym kieruje duchowny szyicki doktor Mohammad Shomali.

Wspomniane organizacje odzwierciedlają etap profesjonalizacji dialogu międzyreligijnego oraz jego instytucjonalizację, silnie postępującą w Iranie po roku 1989. Niewątpliwie jednak intensyfikacja tego procesu zbiegła się z okresem prezydentury Mohammada Chatamigo. Fakt, że przywołane organizacje $\mathrm{w}$ większości stanowią pokłosie działań rządowych, każe umieścić irańskie inicjatywy na rzecz dialogu w kontekście społeczno-politycznym. Instytucjonalne działania obliczone są na promocję szyizmu, dotykają zatem konieczności prowadzenia dialogu w obrębie świata muzułmańskiego, a przy tym również zbliżenia między religiami. Nie tyle w celach czysto poznawczych, co raczej pragmatycznych, do których zaliczyć można działania na rzecz pokoju oraz walkę z terroryzmem. Promowanie Iranu na forum międzynarodowym przy wykorzystaniu instytucji zajmujących się dialogiem międzynarodowym oraz podejmowane inicjatywy pokojowe nie mają jednak, paradoksalnie, bezpośredniego przełożenia na jakość życia mniejszości religijnych w samym Iranie.

\section{INTERIORYZACJA DIALOGU: REWOLUCJA I MNIEJSZOŚCI RELIGIJNE W IRANIE}

Przywołana wcześniej konstytucja Islamskiej Republiki Iranu gwarantuje prawa mniejszościom religijnym, wymieniając wśród nich: chrześcijan (masihi), żydów (kalimi), zaratusztrian (zartoszti). W odniesieniu do chrześcijan pojawia się jeszcze dookreślenie etniczne - chodzi tu o Ormian i Asyryjczyków. A zatem inne społeczności, jak wyznawcy religii Baha’i czy Irańczycy, którzy przyjęli chrześcijaństwo, nie posiadają żadnych praw ${ }^{22}$. Odrębność mniejszości potęguje jeszcze etniczność, za

${ }^{22} \mathrm{Na}$ temat sytuacji bahaitów w Iranie zob.: M. Yazdani, The Islamic Revolution's internal other: the case of Ayatollah Khomeini and the Baha'is of Iran, "Journal of Religious History" 36 (2012) 4, s. 593-604; F. Kazemzadeh, The Baha'is of Iran: twenty years of repression, „Social Research” 67 (2000) 2, s. 537-558. Fenomen „nowych” chrześcijan w Iranie przedstawia praca: M. Bradley, Too Many to Jail. The Story of Iran's New Christians, Oxford-Grand Rapids 2014. 
wyjątkiem zaratusztrian ${ }^{23}, \mathrm{w}$ odniesieniu zaś do chrześcijan elementem odróżniającym będzie dodatkowo używany przez nich język ${ }^{24}$. W teokratycznym Iranie mamy powrót do postrzegania mniejszości w ramach muzułmańskiej kategorii ludów księgi (pers. ahl-e ketāb). Dodatkowo w kontekście Iranu warto zwrócić uwagę, że również nacjonalizm, od którego odżegnują się przywódcy, odgrywa pewną rolę w określaniu mniejszości.

Przyznany grupom religijnym status mniejszości określa ich podmiotowość, ale również podkreśla ich obcość oraz inność, rozpoznaną wprawdzie i zaakceptowana, lecz niepodlegającą negocjacji. Wspomniane społeczności nie stanowią liczebnych grup, a dodatkowo jednak ich populacja zmniejsza się po rewolucji systematycznie ${ }^{25}$. Nie można jednak zaprzeczyć, że rozwiązania prawne stanowią w znacznym stopniu sposób ich ochrony, wsparty nierzadko osobistym autorytetem prawników szyickich. I tak na przykład ajatollah Mohammad Beheszti (1928-1981) jeden z twórców konstytucji Islamskiej Republiki Iranu - zapewniał mniejszości, iż osobiście będzie bronił ich praw. Nie sposób pominąć też ajatollaha Chomejniego i jego stosunku do mniejszości w Iranie. Podobnie politycy oraz duchowni jak Mohammad Szabestari czy prezydenci Ali Akbar Rafsandżani, który utrzymywał osobiste kontakty z przedstawicielami mniejszości religijnych, oraz Mohammad Chatami wnieśli znaczny wkład w ożywienie dialogu międzyreligijnego w wymiarze wewnątrzpaństwowym.

Pojawia się pytanie o formy dialogu, a tym samym również o możliwości, jakie daje mniejszościom państwo, by te wyrażały własne przekonania. Znów jednak musimy zwrócić uwagę na poszczególne etapy rozwoju Islamskiej Republiki Iranu. Niewątpliwie dla pierwszego okresu

${ }^{23}$ Szczegółowe omówienie problemów tożsamości przynosi praca: P. Niechciał, Mniejszość zaratusztriańska we współczesnym Teheranie, Kraków 2013.

${ }^{24}$ L. Balbont, Zakazany język, w: Czarna księga prześladowań chrześcijan w świecie, red. J.-M. di Falco, T. Radcliffe, A. Riccardi, tłum. B. Baran, J. Gorecka-Kalita, M. Szewc-Osiecka, Poznań 2015, s. 303-310.

${ }^{25}$ M. Hemmasi, C.V. Prorok, Demographic changes in Iran's officially recognized religious minority populations since the Islamic Revolution, "African and Assian Studies” 1 (2000) 2, s. 63-86. Najnowsze opracowanie: J. Barry, 'This is not Our Country': Declining Diversity in the Islamic Republic of Iran, „The Muslim World” 105 (2015) 3, s. 281-298. 
istnienia republiki charakterystyczny był konflikt oraz próby negocjowania przez przedstawicieli mniejszości miejsca w nowej rzeczywistości politycznej i społecznej państwa. Integracja w nowym systemie zasadzała się na konieczności przyjęcia określonych wartości kulturowych. A jej przejawem był udział w wydarzeniach wpisujących się w dyskurs tożsamościowy. Do nich należy w pierwszej kolejności partycypacja w rewolucji, w drugiej zaś udział w wojnie iracko-irańskej, określanej w Iranie jako „święta obrona” (defä-e moqaddas). Warto w tym kontekście wspomnieć o męczeństwie będącym jednym $\mathrm{z}$ ważniejszych elementów budowania tożsamości porewolucyjnego Iranu. Męczeństwo utożsamiane z poświęceniem oraz ofiarą dla państwa - Republiki Islamskiej - stało się wartością kulturową ${ }^{26}$ i podstawą waloryzowania społeczeństw, grup, a w końcu również mniejszości zamieszkujących Iran. Męczeństwo przekształciło się w przestrzeń dialogu, z której korzystają mniejszości uczestnicząc w uroczystościach poświęconych ofiarom rewolucji wojny. Państwo zaś uznaje ich poświęcenie $^{27}$. A zatem momentem inicjującym dialog, zwłaszcza w odniesieniu do mniejszości w Iranie, będzie wspólnota doświadczeń ${ }^{28}$.

Akcentowana przez ajatollaha Chomejniego konieczność sprzeciwu wobec wszelkich form opresji zdaje się, w kontekście dialogu międzyreligijnego, przyznawać większą wartość praktyce, a nie teorii. W takim ujęciu wspólnota doświadczeń będzie zarówno formą włączenia, jak również wyłączenia, usuwającą na margines te grupy, które nie mogą legitymizować się podobną do uczestników wojny z Irakiem ofiarnością.

Spośród mniejszości rozpoznanych prawnie w Iranie najliczniejszą grupę stanowią chrześcijanie. Warto w tym miejscu podkreślić, iż rzeczywiście skala zainteresowania chrześcijaństwem w tym kraju jest ogrom-

${ }^{26}$ Zob. R. Varzi, Warring souls. Youth, media, and martyrdom in post-revolutionary Iran, Durham-London 2006.

27 Doskonałym przykładem „rozpoznania” mniejszości oraz ich wkładu w budowanie nowego Iranu jest ekspozycja w Muzeum męczenników w Teheranie poświęcona chrześcijanom, żydom i zaratusztrianom. Więcej o muzeum: Ch. Gruber, The Martyrs' Museum in Tehran: Visualizing Memory in Post-Revolutionary Iran, „Visual Anthropology" 1 (2012) 1-2, s. 68-97.

28 Wartość doświadczenia w budowaniu dialogu podkreślają również dysydenci irańscy. Akbar Ganji podkreśla wartość cierpienia jako podstawy praw człowieka, zob. tenże, The road to democracy in Iran, Cambridge, Mass.-London 2008, s. 6. 
na. Przez długi czas jednak debatę poświęconą chrześcijaństwu określał kontekst społeczno-polityczny, przy jednoczesnym braku zainteresowania wymiarem intelektualnym. Sasan Tavassoli, Irańczyk, konwertyta na chrześcijaństwo i duchowny prezbiteriański, wskazuje jednak na zmiany, jakie zachodzą w nastawieniu uczonych irańskich do chrześcijaństwa w ostatnich latach. Dowodzi on, że obecnie wbrew stereotypowym sądom społeczeństwo irańskie cechuje niespotykany w regionie ferment intelektualny ${ }^{29}$, przejawiający się, między innymi, w odwołaniach do chrześcijaństwa ${ }^{30}$. Mówiąc jednak o chrześcijaństwie, nie sposób pominąć kontekstu międzynarodowego.

\section{DIALOG PONADLOKALNY: SZYICKI IRAN WOBEC KOŚCIOŁA RZYMSKO-KATOLICKIEGO}

Zróżnicowany stosunek Irańczyków do chrześcijaństwa w pełni ukazują pierwsze miesiące rewolucji, działania władz dowodzą zaś odmiennego podejścia do dialogu rozumianego bądź jako narzędzie dyplomacji w stosunkach międzynarodowych, bądź jako środek służący niwelowaniu napięć wewnątrz kraju. W takim ujęciu chrześcijaństwo zostało wpisane w kontekst kultury rewolucyjnej, jako część irańskiej historii lub, przeciwnie, potraktowane jako element obcy. Dwoistość rozumienia dialogu i niejednoznaczność w podejściu do chrześcijaństwa dobrze obrazują relacje władz irańskich z Kościołem rzymsko-katolickim. W czasie rewolucji Nuncjatura Apostolska w Teheranie nieprzerwane prowadziła działalność. Nuncjusz apostolski arcybiskup Annibale Bugnini aktywnie włączał się w mediacje między nową rewolucyjną władzą a mniejszościami religijnymi ${ }^{31}$, uczestnicząc w spotkaniach z ajatollahem Chomejnim.

${ }^{29}$ S. Tavassoli, Christian encounters with Iran. Engaging Muslim thinkers after the revolution, London-New York 2011, s. 1.

${ }^{30}$ M. Smurzyński, Odwołania do protestantyzmu w dyskursie reformatorów islamu szyickiego w porewolucyjnym Iranie, „Orientalia Christiana Cracoviensia” 1 (2009), s. 109-113.

${ }^{31}$ Nuncjusz jest również autorem pracy poświęconej chrześcijaństwu w Iranie, zwłaszcza część poświęcona okresowi poprzedzającemu rewolucję wydaje się dziś niezwykle ciekawa: A. Bugnini, La Chiesa in Iran, Roma 1981. 
10 listopada 1979 roku nuncjusz przebywał w Kom, gdzie ajatollah w jego obecności oraz w towarzystwie Bani Sadra, pełniącego wówczas funkcję ministra spaw zagranicznych, odczytał odpowiedź na otrzymany niespełna kilka dni wcześniej list Jana Pawła II, w którym upominał się on o prawa uwięzionych przez rewolucjonistów dyplomatów amerykańskich. Dowodzi to postrzegania głowy Kościoła rzymsko-katolickiego jako partnera dialogu $\mathrm{u}^{32}$.

Odpowiedź Chomejniego wydaje się kluczowa dla zrozumienia irańskiej koncepcji dialogu. Ukazuje bowiem tak charakterystyczne dla irańskiej rewolucji przewartościowanie historii oraz połączenie dyskursu narodowościowego z religią. Zwracając się bezpośrednio do papieża Jana Pawła II, ajatollah postulował konieczność okazania przez chrześcijan szacunku narodowi irańskiemu jako wyrazu wzajemności. Koran - dowodził z estymą - odnosi się do Jezusa. Chomejni podkreślał, ze Irańczycy podążają za wskazaniami islamu, który z jednej strony nakazuje szacunek dla innych, z drugiej zaś wymaga sprzeciwu wobec tyranii. Islam - konkludował - „nie pozwala na tworzenie dyktatury” ${ }^{33}$. W wypowiedziach Chomejniego islam jawi się jako siła społeczna jednocząca i aktywizująca jednostki, dynamizująca procesy i przemiany polityczne, warunkująca odbiór przeszłości i determinująca wizję przyszłości. Wizja ta łączy silny idealizm, którego źródłem jest zarówno mistyczna koncepcja człowieka doskonałego z pragmatyczną postawą, wynikającą z interpretacji szyizmu jako religii sprzeciwu ${ }^{34}$. Chomejni definiuje przestrzeń dialogu w kategoriach postaw oraz działań, a nie jedynie wymiany myśli, poglądów, czy idei. O przewadze pragmatycznego nastawienia może świadczyć życzliwe stanowisko wobec melkickiego arcybiskupa Hilariona Capucciego, który ze względu na związki z Organizacją Wyzwolenia Palestyny mógł uczestniczyć w negocjacjach w sprawie uwięzionych Amerykanów.

32 B. W. Jones, How does a Born-Again Christians deal with a Born-Again Moslem? The Religious dimension of the Iranian hostage crisis, „Diplomatic History” 39 (2015) 3, s. 431 .

${ }_{33}$ R. Chamejni, Sachanrāni (19 ābān 1357), w: tenże, Sahife-je Emām-e Chamejni, tom 11, Tehrān 1389 (2010) s. 29-39.

${ }^{34}$ H. Dabashi, Shi'ism. A religion of protest, Cambridge, Mass.-London 2011. 
Zupełnie jednak inaczej wyglądało definiowanie katolicyzmu w samym Iranie. Charles Frazee w pisanym pod wpływem rewolucji artykule ${ }^{35}$ zauważa, że nowy system usunął wszelkie możliwości, jakie stwarzał katolikom w Iranie okres panowania szacha Mohammada Rezy Pahlawiego. W Iranie po 1979 roku zamknięto szkoły katolickie, aresztowano kilkoro duchownych katolickich pracujących w Iranie, inni, w tym arcybiskup Kevin Barden, zmuszeni byli do opuszczenia kraju. Wydarzenia z okresu rewolucji dowodzą, że zaakceptowano obecność Kościoła rzymsko-katolickiego w Iranie w wymiarze politycznym, jako reprezentanta Stolicy Apostolskiej, pozbawiając go jednocześnie możliwości prowadzenia tych działań, które rozwijał w XX wieku na polu edukacji oraz kultury.

Badacze irańscy skłonni są upatrywać w spotkaniu Chomejniego z nuncjuszem Bugninim przejawów dialogu pomiędzy Islamską Republiką Iranu a Stolicą Apostolską - „dwoma państwami bezpośrednio odnoszącymi się do religii” (dosłownie doulat-e dini „państwami religijnymi”) ${ }^{36}$. W tym duchu też należy postrzegać spotkanie prezydenta Chatamiego z papieżem Janem Pawłem II w 1999 roku, a w 2006 z papieżem Benedyktem XVI, a w styczniu 2016 prezydenta Ruhaniego z papieżem Franciszkiem. Pewną rolę w inicjowaniu spotkań odgrywają duchowni szyiccy, a zarazem dyplomaci pracujący w irańskiej ambasadzie przy Stolicy Apostolskiej. W promocji dialogu szyicko-chrześcijańskiego znacznie wyróżnia się wspomniany już Masdżed-dżāme’i. Postrzega on jednak dialog międzyreligijny pragmatycznie, dowodząc konieczności pogłębiania kontaktów $\mathrm{z}$ autorytetami religijnymi w świecie celem wzmocnienia pozycji Iranu w regionie oraz na arenie międzynarodowej ${ }^{37}$. Daje on tym samym prymat dyplomacji konfesyjnej nad dyplomacją konwencjonalną.

Istotną rolę w promocji dialogu międzyreligijnego odgrywają wspomniane już wcześniej instytucje. W kontekście dialogu między szyizmem a katolicyzmem najważniejszą zdaje się odgrywać Centrum Dialogu Religii i Cywilizacji, którego partnerami są: Papieska Rada ds. Dialogu Międzyreligijnego, Instytut Świętego Archanioła Gabriela w Austrii oraz inne

${ }^{35}$ Ch. A. Frazee, Catholics and Iran's Revolution, „America” 6/2/1979, t. 140, nr 21, s. 449-450.

${ }^{36}$ M. H. T. Akradi, Piszine-je, s. 261.

${ }^{37}$ M. Masdżed-dżāme’i, Gofrogu-je dini, goftogu-je tamadoni: eslām wa masihijat dar douron-e dżadid, Tehrān 1379 (2000), s. 4. 
instytucje. Jednym z przejawów współpracy są konferencje poświęcone dialogowi. Pierwsza wspólnie z Papieska Radą ds. Dialogu Międzyreligijnego odbyła się w 1995 roku w Teheranie, a jej tematem przewodnim była nowoczesność. Spotkania odbywały się w kolejnych latach - w 1998 w Rzymie („Islam i chrześcijaństwo w zderzeniu z pluralizmem”), w 2001 w Teheranie („Młodzież, tożsamość i edukacja religijna”), w 2003 w Rzymie („Filary pokoju: sprawiedliwość, prawda, miłość i wolność”), w 2005 w Teheranie („Moralność z perspektywy widzenia islamu i katolicyzmu”), w 2008 w Rzymie („Wiara i rozum”), w 2010 w Teheranie („Religia i społeczeństwo”), w 2012 w Rzymie („Współpraca muzułmanów i katolików na rzecz promocji sprawiedliwości we współczesnym świecie”).

Warto też wspomnieć o inicjatywach wspólnot monastycznych (skupionych wokół inicjatywy Monastic Interreligious Dialogue) i szyickich duchownych na rzecz dialogu międzyreligijnego. W 2003 roku w Londynie odbyło się pierwsze spotkanie pomiędzy mnichami i mniszkami benedyktyńskimi a szyickimi duchownymi ${ }^{38}$. Poświęcone było zagadnieniom duchowości oraz modlitwy. Zorganizowano je we współpracy z Heythrop College w Londynie, instytucji, która w późniejszych latach inicjowała podobne spotkania poświęcone relacjom katolicko-szyickim ${ }^{39}$. Konferencje, sesje oraz prowadzone dyskusje wnoszą do irańskiej idei dialogu również elementy poznawcze pozbawione pragmatyczno-politycznych aspektów. Mohammad Ali Shomali uczestnik wielu z wymienionych powyżej spotkań kładzie nacisk na rozwój studiów poświęconych dialogowi. Za taki należy uznać inicjatywę przetłumaczenia Katechizmu Kościoła Katolickiego na język perski przez Uniwersytet Wyznań i Religii w Kom. Katechizm w tłumaczeniu Ahmada Rezy Meftaha, Hosseina Soleimaniego oraz Hasana Qanbariego ukazał się w 2014 ${ }^{40}$. Przedmowę napisał kardynał Jean-Louis Tauran, przewodniczący Papieskiej Rady ds. Dialogu Międzyreligijnego. Inicjatywa podjęta przez uczonych szyic-

${ }^{38}$ W. Skudlarek, M. A. Shomali, Monks and Muslims II: Creating Communities of Friendship, Collegeville, Minnesota 2014.

${ }^{39}$ Owocem tych spotkań były publikacje: A Catholic - Shia Engagement: Studies in Theology and Spirituality, London 2003; A Catholic - Shia Engagement: Faith and Reason in Theory and Practice, London 2006; A Catholic - Shia Engagement: Dialogue Ethics in Today's Society, London 2011.

40 Ta’lim-e Kelisa-je Katulik, Qom 1393 (2014). 
kich dowodzi ewolucji postaw Irańczyków wobec idei dialogu międzyreligijnego, wskazując jednocześnie na wzrost znaczenia badań poświęconych istotnym dla poznania katolicyzmu tekstom.

\section{ZAKOŃCZENIE}

Niewątpliwie wymiernym przejawem rewolucji był niejako wpisany w naturę Islamskiej Republiki Iranu wzrost zainteresowania religiami przy jednoczesnej silnej promocji szyizmu. Ma to istotne znaczenie dla wszelkich inicjatyw związanych z szeroko rozumianym dialogiem ze światem muzułmańskim. Ukazuje bowiem zróżnicowanie islamu oraz konieczność uwzględnienia wewnętrznych napięć i sporów w obrębie tej religii.

Wzrost zainteresowania religiami przejawia się również $\mathrm{w}$ zakładaniu ośrodków zajmujących się dialogiem międzyreligijnym oraz powoływaniu instytutów badawczych o charakterze religioznawczym. Paradoksalnie w niewielkim stopniu przekłada się to na działania na rzecz mniejszości religijnych zamieszkujących Iran. Programowe badania religii, zwłaszcza w ośrodkach dofinansowanych przez państwo i ideologicznie zgodnych $\mathrm{z}$ doktryną państwową, traktują chrześcijaństwo (ale też inne religie) jako element obcy, pozbawiając go nierzadko wymiaru lokalnego.

Dialog międzyreligijny odgrywa niewątpliwie bardzo istotną rolę w dzisiejszym Iranie. Daje się jednak zauważyć znaczną różnicę w sposobach jego definiowaniu przez uczonych szyickich oraz teologów chrześcijańskich. Różnica ta zasadza się na zgoła odmiennym potraktowaniu religii w polityce. Przy braku rozgraniczenia między tym, co polityczne, a tym, co religijne, dialog międzyreligijny staje się częścią dyplomacji oraz promocji Iranu na forum międzynarodowym. Rozumiany jest on praktycznie jako sposób rozwiązywania określonych problemów i odpowiada zmianom zachodzącym w tym kraju i ciągłej konieczności uaktualniania dyskursu rewolucyjnego.

W 2002 roku James A. Bill oraz John Alden William, publikując pierwszą pracę $\mathrm{w}$ całości poświęconą relacjom między Kościołem rzymsko-katolickim a szyizmem, dowodzili, że systematyczne studia poświęcone temu zagadnieniu nie były, jak dotąd, podejmowane ${ }^{41}$. Niewątpliwie

${ }^{41}$ J. A. Bill, J. A. William, Roman Catholics and Shi'i Muslims, Chapel Hill-London 2002, s. 3. 
wiele zmieniło się od tego czasu. Obecnie we wspólnych debatach uczonych szyickich i katolickich dominuje jednak problematyka etyczno-prawna, zagadnienia związane $\mathrm{z}$ relacjami między wiarą a rozumem, źródłami autorytetu religijnego czy strukturalnym znaczeniem tworzenia wspólnoty. Rozważane są takie fenomeny jak męczeństwo, ofiara, poświęcenie w religii. Wydaje się też, że ożywiony dialog z Kościołem rzymsko-katolickim, w pewnym przynajmniej stopniu, ujawnia roszczenia Iranu do reprezentowania wszystkich szyitów, niezależnie od ich pochodzenia. A w takim ujęciu irańskie centrum religijne w Kom, w którym mieszczą się ważne instytucje zajmujące się dialogiem międzyreligijnym, miałoby funkcjonalnie odpowiadać Watykanowi.

Streszczenie. Przebudzenie muzułmańskie a świat chrześcijański. Pragmatyka dialogu międzyreligijnego w porewolucyjnym Iranie. Rewolucja islamska w Iranie pociągnęła za sobą konieczność przebudowy systemu politycznego oraz redefiniowania pozycji państwa w otoczeniu międzynarodowym. Użytecznym narzędziem prowadzenia polityki wewnętrznej oraz zewnętrznej stał się dialog międzyreligijny. W systemie politycznym Iranu dialog międzyreligijny nabrał charakteru pragmatycznego, a jego rozumienie w dużym stopniu warunkowały zmiany społeczne i polityczne. W wymiarze wewnętrznym stał się środkiem w kontaktach z zamieszkującymi kraj mniejszościami religijnymi (zaratusztrianie, żydzi, chrześcijanie) zaś w wymiarze zewnętrznym częścią prowadzonej polityki zagranicznej. Dotyczy to przede wszystkim relacji ze Stolicą Apostolską, które intensyfikują również inicjatywy na rzecz głębszego zrozumienia doktryn oraz struktury Kościoła rzymsko-katolickiego.

Słowa kluczowe: Iran; rewolucja islamska; dialog; chrześcijaństwo; Watykan; Kościół rzymsko-katolicki.

Abstract. Muslim awakening and the Christian world. Pragmatics of inter-religious dialogue in the post-revolutionary Iran. The Islamic revolution in Iran caused the process of rebuilding the state's political system and redefining its position in international system. The inter-religious dialogue became a useful tool in both internal and external state's policy. Within Iranian political system the dialogue took more pragmatic character and was interpreted in the context of social and political changes. In internal policy it became an important factor for defining the religious minorities' rights (Zoroastrians, Jews, Christians), in external - a part of foreign policy. It refers, above all, relations between Iran and the Holy See, intensifying initiatives for a deeper understanding doctrines and structure of the Roman Catholic Church.

Keywords: Iran; Islamic Revolution; dialogue; Christianity; Vatican; Roman Catholic Church. 
